\title{
Personalized versus Normal Practice of L2 Speaking on Iranian EFL Learners' Oral Proficiency
}

\author{
Ayda Rahmani \\ Comprehensive University of Applied and Practical Sciences, Culture and Art, Unit 2 \\ Nowshahr, Mazandaran, Iran \\ E-mail: ayda.peace@gmail.com
}

Received: 27-08-2014

Accepted: 24-10-2014

Published: 01-03-2015

doi:10.7575/aiac.ijalel.v.4n.2p.151

URL: http://dx.doi.org/10.7575/aiac.ijalel.v.4n.2p.151

\begin{abstract}
Personalized learning is a self-initiated, self-directed or self-prioritized pursuit which gives the learner a degree of choice about the process of learning i.e. what to learn, how to learn and when to learn. Of course personalized learning does not indicate unlimited choice; because, L2 learners will still have targets to be met. However, it provides learners with the opportunity to learn in ways that suit their individual learning styles. The L2 learner should have the opportunity to freely choose a series of activities, already predisposed by the teacher, to improve and develop L2 proficiency. This is because human beings have different ways to learn and process information; and, these different ways of learning are independent of each other. In other words, learning styles and techniques differ across individuals; thus, personalized learning provides L2 learners to freely choose the activities they enjoy the most. So it is a studentcentered learning method in which the interests and the preferences of the learner is taken into account.The present study is an investigation of a personalized versus normal practice of L2 proficiency. For this purpose an OPT (Oxford Placement Test) was given to a total of 80 Iranian EFL learners. Then, 40 of them who were considered as intermediate learners were selected for the purpose of the study. The participants were randomly divided into two groups i.e. an experimental group and a control group. Both groups were pretested prior to the study. Then, the experimental group received the treatment in the form of personalized learning (games-based learning, songs, music, stories, English tongue twisters and the materials that the subjects were most interested in) for ten sessions while the control group received a normal practice of speaking proficiency (based on New Interchange course books). After ten sessions, both groups were post tested. Then the results of the posttests were subjects of statistical analysis (independent-samples t-test). The results indicated that the experimental group did better than the control group and there is a significant difference between the mean scores of the experimental group who were exposed to a personalized learning and the control group who received a normal practice of oral proficiency i.e. a placebo. Based on the results of this study, L2 learner' interests in carrying out joyful L2 activities can help to reach promising results.
\end{abstract}

Keywords: Personalized learning, Oral proficiency, EFL learners, Communication

\section{Introduction}

Iranian EFL learners have problems in L2 writing proficiency according to Danesh(2003), Seifoori (2009), Zenjanab (2010), Kolahi (2010), and the researcher's own teaching experience. Many Iranian EFL learners find it difficult to get their meanings across in the second language. Speaking is an important skill because it is a crucial part of daily life but speaking is not limited to just producing utterances i.e. one of the necessary aspects of 'speaking' is that it always occurs in cultural and social contexts. In fact, L2 speaking is complex because many components should be at work simultaneously. Perhaps one of the problems of Iranian EFL learners' L2 speaking is that they are mostly concerned about grammar and accuracy. Thus, while speaking, they often pause and anxiously concentrate on grammatical structure of their utterances which prevents their speech being fluent. Most of them have been exposed to traditional methods which were based on grammar and memorization of grammatical rules; so, naturally they are too much obsessed about grammar rather than expressing themselves in L2. Another problem may be anxiety and stress while expressing themselves in L2. Many of the EFL learners are afraid of mispronunciation, mistakes and being laughed at. Such L2 learners prefer to be silent and resort to muteness. In addition, some Iranian EFL learners know enough vocabulary and grammatical rules; however, they still find it difficult to converse and communicate in L2. So communication in English has become a major challenge for many Iranian EFL learners. English is now the international language of the world and its globalization as a worldwide phenomenon has made it crucial for many people to learn how to communicate with people of other countries and cultures. This paper is written to highlight the importance of personalized learning for improving L2 speaking and lessening L2 learners' sense of uneasiness while expressing themselves in $\mathrm{L} 2$.

According to Burns (2001), every time we open our mouth to say even a short utterance, different things occur at the same time that fall within the scope of pronunciation. We can say a phrase, loudly, slowly, softly or quickly with a certain voice quality, with a certain speech melody or stress. There are different ways of saying the same individual sounds. All these elements together, make up the way we sound to our audience. The way we sound to our interlocutor 
is an important matter which cannot be overlooked. Because this is how we convey and express our identity, personality and character as social beings. Interlocutors are those with whom we get judged. There are different issues that we not to take into account while speaking such as our relationship with the audience, adjusting our language according to the situation and context, and the listener.

Kolahi (2010) stated that there is no significant difference between the impacts of prompts and recasts on the frequency of phonological and lexical errors. Her research aimed to investigate the differential impact of prompts and recasts on the phonological, grammatical, and lexical errors of Iranian EFL university students.161 male and female university students majoring in English language translation took part in her study. They were pretested and post tested. The participants' answer to the questions were recorded, transcribed and coded for the frequency of phonological, grammatical and lexical errors. According to the analyses, prompts and recasts were both effective in reducing the frequency of phonological, grammatical and lexical errors of the participants' oral discourse. However prompts, in comparison with recasts were more effective in reducing the frequency of grammatical errors. Also, there was no significant difference between the impacts of prompts and recasts on the frequency of phonological and lexical errors.

According to the researchers' own experience the overall learning atmosphere and environment affect the way L2 learners react and respond to the whole learning process. In a relaxed situation, where a sense of belonging is created, L2 learners feel a sense of togetherness. Thus, they are more likely to express their ideas in L2 even if they know that what they produce is grammatically or phonologically incorrect. L2 learners spend a lot of time to develop their syntactic and semantic competencies but they are still unable to have an effective participation in L 2 speaking. They fail to express their intended meaning with so many words and grammatical rules they have in mind. Some common reasons maybe fear of possible spoken errors, awkward pronunciation, intonation, lack of self-confidence, fear of losing face in front of others and the teachers' reactions to their errors and mispronunciations. As a result, teachers' role is very important to make or mar the future performance and perception of EFL learners. Teachers can both encourage and discourage EFL learners from speaking in L2 by their reactions and the way they provide feedback.

So the present study is an attempt to investigate the results of a personalized L2 speaking classroom where L2 learners listen to what they enjoy in L2, and have free discussions on topics they like (a classroom in which the L2 learners' likes and dislikes are taken into consideration, games-based learning is welcomed, and the learning process is customized according to L2 learners' interests). In this way, L2 learners who are reluctant or afraid to speak will feel confidence, inner motivation and inspiration which pave the way for them to take a positive constructive step towards L2 oral proficiency.

The significance of this research is the influence which it could have on the way L2 speaking proficiency will be enhanced. There is a consensus of opinion among Iranian of all walks of life on the need to improve the standard of English in Iran. Efforts are being made to improve the teaching and learning of the EFL learners in Iran and this present study seeks to find out a way to help Iranian L2 learners in developing and improving their L2 oral skill. The findings of this study will serve as a data-base for teachers, text-book writers and EFL teachers towards the improvement of L2 speaking ability. EFL learners need to be exposed to a personalized practice to improve their oral L2 output. The findings of the present study will assist the teachers in maximizing the knowledge of Iranian EFL learners' by using a personalized practice in which the students' needs and interests are taken into consideration. Based on this objective, the research question was conducted.

\section{Literature review}

According to Lazaraton (1996), the most difficult or demanding aspect of speaking English as a second language, is that it mostly involves interaction; it is actually accomplished via interaction with at least one speaker. This means that different psycholinguistic and sociolinguistic systems need to be in place at the same time and at once. An L2 speaker needs to monitor his/ her speech, think, and understand the interlocutor simultaneously. So spontaneous L2 speaking is difficult and many find their first real interaction in second language as disappointing and shocking. Today, the main aim of many ESL classrooms is to negotiate meaning and to get meaning across. Learning is no longer seen as a oneway of transferring knowledge from teacher to student. This is because students learn not only from teachers but from classmates and environment outside the class also. An oral skill class, certain matters need to be taken into account for example, the level of the EFL learners, their needs and expectations. Today, oral skills classes focus on functional uses of language such as daily greetings, shopping, socializing, etc. There are many activities to help L2 learners improve their oral proficiency such as free discussions, role-plays, conversations, and the like.

According to Goodwin (1996), teaching of pronunciation is very important to L2 students; because, pronunciation is the feature that identifies L2 speakers as non-native speakers. Interlocutors and listeners see speakers through the filter of their pronunciation. The accent of L2 speakers should not be distracting to the listener. L2 learners seldom achieve an accent-free pronunciation so at least, their pronunciation should not be distracting. They need to gain enough inner confidence to produce utterances and they need to be understood by their teacher. On the other hand, teachers should help students to monitor and evaluate their own utterances and to make the best of the input they receive.

Nunan (1999) stated that in order to speak in another language, a person needs to know not only how to articulate sounds in a comprehensible manner, but also how to use an adequate vocabulary and syntax. These elements refer to linguistic competence. However, linguistic competence is necessary but not enough for someone who wants to converse in L2. In 1974, Dell Hymes, mentioned and suggested the idea of communicative competence which includes linguistic competence, pragmatic competence, and intercultural competence also. 
Sheikhrezai (2010) conducted a research regarding L2 speaking according to which metalinguistic corrective feedback has a statically significant impact on the speaking development of Iranian EFL learners. Her study was an attempt to find out whether metalinguistic corrective feedback, as a type of corrective feedback, has any impact on the speaking development of learners with different levels of language proficiency. To reach this aim, 39 subjects out of 80 students were selected after CELT proficiency test. An interview was administered as the pretest. The subjects were given the needed instructions while the metalinguistic corrective feedback, as a technique of error correction, was also carried out in the class. Then an interview was held as the posttest. The analyzed results showed that metalinguistic corrective feedback has a statistically significant impact on the speaking development of Iranian EFL learners.

Tavoosi (2005) claimed that students, who work with their friends in pairs, outperform those who work in pairs who were chosen by the teacher. She attempted to find out whether friendship among pairs has any effect on increasing the learners' speaking proficiency. The study was carried out on female EFL learners. The scores were given based on three raters. The raters rated the pretest and posttest. The learners' voices were recorded throughout the treatment and each rater gave an individual mark. The scores each rater gave were based on a checklist. Both the experimental group and the control group were given pair work and group work to practice L2 speaking. But the difference was that the pairs in the experimental group were friends who had chosen to work together without the teacher's influence whereas the pairs in the control group were chosen by the teacher to work with one another. After two months of observation, they were all post tested. The results revealed the more improvement of the pairs who were friends.

According to Baghbani (2007), there is no superiority of explicit versus implicit corrective feedback on the improvement of oral accuracy of EFL Iranian learners. Her study investigated the effects of two types of correction techniques on the improvement of oral accuracy of Iranian EFL learners' L2 oral accuracy i.e. direct teacher correction either explicitly or implicitly. The selected participants were given a free discussion as the pretest to determine the learners' oral accuracy. The aim of the study was to empirically determine whether implicit or explicit interactional feedback benefits learners more. The subjects of her study were divided into two groups: the explicit group and the implicit group. The explicit group received explicit interactional feedback in the form of explicit correction and metalinguistic explanation when they make an error while the implicit group received implicit error correction in the form of clarification requests, elicitation, repetition of error, and recasts. The results indicated that explicit correction techniques seems to be more appropriate if it is used to correct only syntactic errors, especially tense errors.

Danesh (2003) stated that language learning is not just a matter of knowing the grammatical forms i.e. the learner needs to apply these forms in the appropriate context and situation. In his research, Danesh answered the question of whether there is a positive relationship between language proficiency and applying the speech acts of complaining, complimenting and advising among Iranian EFL students. His 96 research subjects were given questionnaire to be filled. These questionnaire / function tests specified the extent to which the subjects were able to apply appropriately the aforementioned speech acts in the situation. He used the native speakers' alternatives as the base or criterion for grading the function tests i.e. the questionnaire. The responses of the subjects were categorized as exact response, very near response, near response, far response, and very far response. After collecting the data based on the questionnaire test scores, the correlation between each group's variables and among the whole group variables were calculated through Pearson product- moment correlation coefficient formula. The data analysis indicated that there was a positive significant relationship between language proficiency and applying the speech acts of complaining, complimenting, and advising among Iranian EFL students.

According to Hassani (2008), brainstorming and group brainstorming have a significantly positive impact on the development of Iranian EFL learners' speaking ability at lower intermediate level. Hassani used the speaking scale which is offered by Weir (1993) to measure participants' general speaking ability. After homogenizing the participants, the experimental group received brainstorming while the control group did not receive brainstorming. After the treatment, both groups were pretested and post tested in the form of an interview. The results demonstrated that the treatment was effective and the experimental group outperformed the control group.

According to Farashahi (2003), the application of cooperative learning technique, improves Iranian EFL students' speaking skill. Farashahi's study was an attempt to discover the effects of cooperative learning on Iranian EFL students' speaking skill. Having administered a general proficiency test, sixty participants with the same level of L2 proficiency were selected. Then the 60 subjects were divided into experimental and control groups each containing 30 students. Then, they were all pretested and later post tested to see if the students improved. The students in the experimental group did all the language activities cooperatively whereas the control group did all the exercises and activities individually. The oral posttest determined the degree of the students' improvement in speaking skill. The null hypothesis was rejected because the calculated $t$ exceeded the $t$-critical value for 58 degrees of freedom.

Seifoori (2009) explained that research findings emphasized the role of metacognitive strategies such as task planning in improving oral proficiency. In her study, she investigated the impact of a metacognitive training program on accuracy, complexity, and fluency of task-based oral performance under pre-task planning, on-line task planning, and pre/on-line task planning conditions. She hypothesized that metacognitive training would positively affect all features of oral performance and that simultaneous pre-task and on-line task planning would result in more accurate, more complex and more fluent performance. 120 participants took part in the study and they were randomly assigned to two groups i.e. an experimental group and a control group. Each group was further subdivided into PTP planners, OLP planners, and POLP planners. The data analysis of the post-test results revealed that there were significant effects on accuracy in all planning groups, and on fluency in PTP and POLP groups. But, no effects were fund on complexity. 
Zenjanab (2010) said that the planned focus on form improves Iranian EFL learners' oral accuracy in comparison to an incidental focus on form. She conducted a study to compare the impacts of planned/incidental focus on form on the grammatical accuracy of Iranian EFL learners' oral production at the intermediate level of language proficiency. She used Nelson Proficiency Test and an interview to choose the appropriate subjects for her study. Then she established two groups. One group was exposed to planned focus on form and the other group was exposed to incidental focus on form. After 10 sessions, both groups were post-tested by an interview to measure their achievements over the target structure (English relative clause). The results showed improvements in both groups from the pretest to the posttest. However, there were significant improvements for planned focus on form group in comparison with incidental focus on form group.

2.1 Research question

Q1. Is there any significant difference between the pre-test and post-test scores of the control group (who were exposed to a placebo)?

Q2. Is there any significant difference between the pre-test and post-test scores of the experimental group (who were exposed to personalized learning)?

Q3. Does a personalized practice of L2 speaking skill affect Iranian EFL Learners' oral proficiency?

\section{Hypothesis}

H0. Using a personalized practice of L2 speaking does not have a significant effect on Iranian EFL learners' oral proficiency.

\section{Methodology}

\subsection{The Subjects}

The participants of this study were 40 homogenous EFL learners (i.e. they had the same L2 proficiency level) who were studying at Marlik Higher Education Institute, Nowshahr, Iran. The participants of the study were both male and females, native speakers of Persian and in their early twenties. Also, they had not been to English speaking countries. Their average exposure to English was about 6 years during which they had received a traditional version of language learning syllabus and curriculum. Based on a placement test and an interview, they were considered intermediate learners. Since they were studying English in Iran only, they were described as foreign language learners. Most of them had received their L2 knowledge (in English language) at school; so, they were exposed to a traditional method of L2 learning. As a result, they had received a grammar-based, teacher-oriented method based on the course book in the classroom.

\subsection{The Procedure}

First an OPT test (Oxford Placement Test) was administered to 80 junior students. After scoring the papers, 40 out of 80 students were selected for the purpose of the study. The participants of this study were randomly assigned into two different groups: an experimental group and a control group. Each group consisted of 20 students who were taking English as a second language during an educational year. The participants were all given a pretest. Then the treatment group received the treatment in the form of being exposed to personalized learning (games-based learning, role plays, students' favorite free discussions, rhythmic songs, L2 learners' favorite short stories, and English tongue twisters) during ten sessions. The classes were held once a week and three hours were scheduled for each session. This study covers a whole term and finally, the participants were given a posttest. Then, the result of a paired samples t-test and pairedsamples t-test and independent-samples t-test became the subject of data analysis.

\subsection{Research design}

This study utilizes a quasi-experimental design. The design of the study was based on a pre-posttest design.

\subsection{Materials and Instruments}

The materials used in the current study were of four sorts: the OPT material for proficiency,

(Participants' proficiency test scores i.e. OPT), the material for the pretest of the study (IELTS speaking sample tests and an interview), the material for the treatment of the study (a variety of different materials such as survival English, academic texts, conversational dialogues, tourism-based texts, short stories, etc. from which L2 learners freely chose to practice what they enjoyed the most), and finally the material for the posttest of the study (IELTS speaking sample tests and an interview). To handle the current study, the data was analyzed on the basis of SPSS (version 20), paired samples ttest and Independent samples t-test. A t-test was run between the scores of the post test of the two groups. Paired samples t-test was run between the scores of the pretest and posttest of the experimental and separately with those of the control group.

\section{Result and Findings}

As it is noted earlier in the previous sections, the present study aimed at investigating the impact of a customized vs. normal practice on Iranian EFL learners' L2 speaking skill. So this section is concerned with data analysis in which the following terms such as group statistic, Paired Samples t-test and independent-samples t-test have been used for analyzing the data which are briefly described below and the main objective of this study is to examine the effectiveness of a customized practice in the speaking of L2 among intermediate students in Nowshahr city of Mazandaran, province of Iran. The obtained data of this study were analyzed by utilizing SPSS (version 21) software. 
Table1. Paired-Samples T-Test (Experimental Group)

\begin{tabular}{|c|c|c|c|c|c|}
\hline & & Mean & $\mathrm{N}$ & Std. Deviation & Std. Error Mean \\
\hline \multirow{2}{*}{ Pair 1} & PostEx & 5.8500 & 20 & 1.08942 & .24360 \\
\hline & PreEx & 2.4500 & 20 & .82558 & .18460 \\
\hline
\end{tabular}

$\underline{1.2 \text { Paired Samples Test }}$

\begin{tabular}{|c|c|c|c|c|c|c|c|c|c|}
\hline & & \multicolumn{5}{|c|}{ Paired Differences } & \multirow{3}{*}{\multicolumn{2}{|c|}{$\mathrm{t} \quad \mathrm{df}$}} & \multirow{3}{*}{$\begin{array}{l}\text { Sig. }(2- \\
\text { tailed) }\end{array}$} \\
\hline & & \multirow[t]{2}{*}{ Mean } & \multirow[t]{2}{*}{$\begin{array}{c}\text { Std. } \\
\text { Deviation }\end{array}$} & \multirow[t]{2}{*}{$\begin{array}{l}\text { Std. Error } \\
\text { Mean }\end{array}$} & \multicolumn{2}{|c|}{$\begin{array}{l}95 \% \text { Confidence Interval of the } \\
\text { Difference }\end{array}$} & & & \\
\hline & & & & & Lower & Upper & & & \\
\hline $\begin{array}{l}\text { Pair } \\
1\end{array}$ & $\begin{array}{l}\text { PostEx - } \\
\text { PreEx }\end{array}$ & 3.40000 & .59824 & .13377 & 3.12001 & 3.67999 & 25.417 & 19 & .000 \\
\hline
\end{tabular}

A paired-samples t-test was conducted to evaluate the impact of a personalized practice on students' scores on L2 speaking proficiency. As Table1 indicates, the mean score of the posttest of the experimental group $(\mathrm{M}=5.8500)$ is higher than the mean scores of the pretest $(M=2.4500)$. Also, $t_{o b s}=25.417$ is more than the critical $t$ which is 2.093 . Thus, the null hypothesis is rejected.

Table 2. Paired-Samples T-Test (Control Group)

\begin{tabular}{rrrrrr}
\hline & Mean & N & & Std. Deviation & Std. Error Mean \\
\hline \multirow{2}{*}{ Pair 1 } & PostCon & 4.1000 & 20 & .85224 & .19057 \\
\cline { 2 - 6 } & PreCon & 2.3500 & 20 & .87509 & .19568 \\
\hline
\end{tabular}

$\underline{2.1 \text { Paired Samples Test }}$

\begin{tabular}{|c|c|c|c|c|c|c|c|c|c|}
\hline & & \multicolumn{5}{|c|}{ Paired Differences } & \multirow[t]{3}{*}{$\mathrm{t}$} & \multirow[t]{3}{*}{ df } & \multirow{3}{*}{$\begin{array}{l}\text { Sig. (2- } \\
\text { tailed) }\end{array}$} \\
\hline & & \multirow[t]{2}{*}{ Mean } & \multirow[t]{2}{*}{$\begin{array}{c}\text { Std. } \\
\text { Deviation }\end{array}$} & \multirow[t]{2}{*}{$\begin{array}{l}\text { Std. Error } \\
\text { Mean }\end{array}$} & \multicolumn{2}{|c|}{$\begin{array}{l}\text { 95\% Confidence Interval of the } \\
\text { Difference }\end{array}$} & & & \\
\hline & & & & & Lower & Upper & & & \\
\hline $\begin{array}{l}\text { Pair } \\
1\end{array}$ & $\begin{array}{l}\text { PostCon - } \\
\text { PreCon }\end{array}$ & 1.75000 & .44426 & .09934 & 1.54208 & 1.95792 & 17.616 & 19 & .000 \\
\hline
\end{tabular}

Table 2 indicates that a paired-samples t-test was conducted to evaluate the impact of a normal practice on students' scores on L2 speaking proficiency. According to Table 2, the observed t value is calculated to be 17.616 and the degree of freedom id 19 (the $\left.\mathrm{t}_{\mathrm{obs}}=17.616, \mathrm{df}=19\right)$ ). Thus $\mathrm{t}$ observe is more than the critical $\mathrm{t}$ which is 2.093 .

Table 3. Independent-Samples T-Test

\begin{tabular}{llrrrr}
\hline & Practicetype & N & Mean & Std. Deviation & Std. Error Mean \\
\hline \multirow{2}{*}{ speaking } & 1.00 & 20 & 5.8500 & 1.08942 & .24360 \\
\cline { 2 - 6 } & 2.00 & 20 & 4.1000 & .85224 & .19057 \\
\hline
\end{tabular}

3.1 Independent Samples Test ( between the posttests only)

\begin{tabular}{|c|c|c|c|c|c|c|c|c|c|c|}
\hline & & \multicolumn{2}{|c|}{$\begin{array}{c}\text { Levene's Test } \\
\text { for Equality of } \\
\text { Variances }\end{array}$} & \multicolumn{7}{|c|}{ t-test for Equality of Means } \\
\hline & & \multirow[t]{2}{*}{$\mathrm{F}$} & \multirow[t]{2}{*}{ Sig. } & \multirow[t]{2}{*}{$\mathrm{t}$} & \multirow[t]{2}{*}{$\mathrm{df}$} & \multirow[t]{2}{*}{$\begin{array}{l}\text { Sig. (2- } \\
\text { tailed) }\end{array}$} & \multirow[t]{2}{*}{$\begin{array}{c}\text { Mean } \\
\text { Difference }\end{array}$} & \multirow[t]{2}{*}{$\begin{array}{l}\text { Std. Error } \\
\text { Difference }\end{array}$} & \multicolumn{2}{|c|}{$\begin{array}{l}95 \% \text { Confidence } \\
\text { Interval of the } \\
\text { Difference }\end{array}$} \\
\hline & & & & & & & & & Lower & Upper \\
\hline \multirow{2}{*}{ speaking } & $\begin{array}{l}\text { Equal } \\
\text { variances } \\
\text { assumed }\end{array}$ & .588 & .448 & 5.658 & 38 & .000 & 1.75000 & .30929 & 1.12388 & 2.37612 \\
\hline & $\begin{array}{l}\text { Equal } \\
\text { variances not } \\
\text { assumed }\end{array}$ & & & 5.658 & 35.919 & .000 & 1.75000 & .30929 & 1.12269 & 2.37731 \\
\hline
\end{tabular}

According to Table3, there were two groups each containing twenty students. The two groups received two different types of L2 speaking practice (i.e. Personalized practice $=1$, Normal Practice=2). The experimental group was exposed to a personalized practice of oral proficiency while the control group was exposed to a normal practice i.e. a placebo. Sig (2tailed) is .000 . which is less than 5 so the null hypothesis is rejected. Also, the mean scores of the experimental group 
who received a personalized practice (mean $=5.8500$ ) is higher than the mean scores of the control group who received Normal practice (mean $=4.1000$ ). Also the critical $t$ is 2.21 which is less than the $t_{o b s}\left(t_{o b s}=5.658\right)$

\subsection{Discussion}

Oral communication in English as a second or foreign language is necessary for many people all around the world. This is because English, as an international language is globalized. So many people need to communicate in English with people of various countries, cultures and places. For many people, knowing a language means being able to speak that language. However, despite many attempts, Iranian EFL learners are still challenging with L2 speaking problems which make them unable to be effective L2 communicators. The present study reported here has made an attempt to discover that a personalized practice of L2 oral proficiency is an effective way for improving Iranian EFL learners' L2 speaking ability.

The analysis of the study reveals that the participants gained more proficiency than did the ones who were in the control group being exposed to a normal practice of L2 speaking. First of all, an OPT (Oxford Placement Test) was administered among 80 subjects 40 of whom were selected for the aim of this study. The subjects were randomly divided in two groups i.e. an experimental group and a control group. For ten sessions, the experimental group received the treatment in the form of being exposed to a personalized practice (i.e. games-based learning, the students' favorite topics for free discussion, English tongue twisters, short stories and rhythmic songs) while the control group received a placebo i.e. a normal practice of L2 speaking proficiency. A pretest was administered prior to the application of the treatment and placebo. Then a subsequent posttest was administered at the end of the duration of the teaching. Then the scores were analyzed through SPSS using a Paired-sample t-test, Independent-samples t-test and Descriptive Analysis. The results demonstrated that there is a significant difference between the mean scores of EFL learners' speaking test as a result of exposure to a personalized practice of L2 speaking. Thus, the null hypothesis was rejected which indicates that the treatment of the study was effective and the subjects in the experimental group outperformed the ones in the control group. The findings of the present study are in line with many studies investigating the impact of various factors on L2 speaking skill. But, the dominant teaching method in Iran has been the traditional grammar-based; however, L2 language teachers should consider the interests and emotional states of their L2 learners as well. Through personalized learning, L2 learners will be exposed to different learning experiences and they will have a degree of choice to address their L2 learning needs.

\section{Implications of the Study}

The findings of this study may have some pedagogical implications. A new outlook on L2 teaching needs to be obtained in our country in order to facilitate L2 speaking skill and to involve the students actively in the process of learning. Based on the results of this study, L2 learners could benefit from personalized learning. One profound implication of the current study is the indication of a great need for a great change in the working system of the educational system regarding teaching English as a foreign language at university levels. Measures need to be taken in order to bring about an alternation in the prospect and perspective of L2 speaking teaching. This notion needs to be noted that the learner should be free of any uneasy feeling or frustration in order to gain certain results in the field of language learning and teaching. Personalized language learning and teaching helps to create a peaceful atmosphere in which learners enjoy the most. The recommendation the researcher would like to extend based on the results of the study is that EFL teachers should devote some classroom time to carry out interesting language activities (what learners enjoy).

\section{References}

Baghbani, M. (2007). The Effect of Explicit vs. Implicit Corrective Feedback on the Improvement of Oral Accuracy of EFL Iranian Learners. Tehran: Islamic Azad University.

Brazil, D. (1997). The Communicative Value of Intonation in English. Cambridge: Cambridge University Press.

Brazil, D., Coulthard, M., \& Johns, C. (1980). Discourse Intonation and Language Teaching. London: Longman.

Burns, A. (2001). Analyzing Spoken Discourse: Implications for TESOL. In Burns, A., Coffin, C. (ed). Analyzing English in a Global Context. London: Routledge; 123-148.

Cook, G. (1989). Discourse. (Language Teaching : A Scheme for Teacher Education). Oxford: Oxford University Press.

Danesh, A. (2003). The Impact of Language Proficiency on Applying Certain Speech Acts Among Iranian EFL Students. Tehran: Islamic Azad University.

Ellis, R. (1994). The Study of Second Language Acquisition. Oxford: Oxford University Press.

Farashahi, A (2003). The Effects of Cooperative Learning on Iranian EFL Students' Speaking Skill. Tehran: Islamic Azad University.

Gardner, R. (1985). Social Psychology and Language Learning: The role of Attitudes and Motivation. London: Edward Arnold.

Gass, S.M., \& Selinker, L. (2008). Second Language Acquisition. Third Edition. Routledge.

Goodwin, J., \& Brinton, D. (1996). Teaching Pronunciation: A Reference for Teachers of English to Speakers of Other Languages. Cambridge University Press.

Halliday, M.A.K., \& Hasan, R. (1976). Cohesion in English. London: Longman.

Halliday, M.A.K. (1989). Spoken and Written Language. Oxford: Oxford University Press.

Hancock, M. (1996). Pronunciation Games. Cambridge: Cambridge University Press. 
Hassani, V. (2008). The Impact of Brainstorming on the Development of Iranian EFL Learners' Speaking Ability at Lower Intermediate Level. Tehran: Islamic Azad University.

Kolahi, Sh. (2010). A comparative Study of the Impact of Prompts and Recasts on the Phonological, Grammatical, and Lexical Errors of Iranian EFL University Students' Oral Discourse. Tehran: Islamic Azad University.

Krashen, S. (1982). Principles and Practice in Second Language Acquisition. Oxford: Pergamon.

Krashen, S. (1981). Second Language Acquisition and Second Language Learning. Oxford: Pergamon.

Lazaraton, A. (1996). Interlocutor Support in Oral Proficiency Interviews: The case of CASE. Language Testing 13:151-172.

Lazaraton , A., and Skuder, A. (1997). Evaluating Dialogue Authenticity in ESL Speaking texts. TESOL Convention, Orlando, FL.

Nunan, D. (1999). Second Language Teaching and Learning. Heinle \& Heinle Publications.

Rivers, W. (1968).Teaching Foreign Language Skills. Chicago, IL: University of Chicago Press.

Schmitt, N. (2002). An Introductory to Applied Linguistics. Arnold Publication, London.

Seifoori, Z. (2009). The Impact of Metacognitive Strategies-based Training and Levels of Planning on Accuracy, Complexity, and Fluency of of Focused Task-based Oral Proficiency. Tehran: Islamic Azad University.

Sheikhrezai, F. (2010). The Effect of Metalinguistic Corrective Feedback on the Speaking Development of the Iranian EFL Learners at Different Levels of Language Proficiency. Tehran: Islamic Azad University.

Swain, M. (2000), The Output Hypothesis and Beyond: Mediating Acquisition through Collaborative Dialogue' in J.Lantolf (ed): Sociocultural Theory and Second Language Learning. Oxford: Oxford University Press.

Tavoosi, S. (2005). Impact of Personal Relationships (Friendship) among Pairs on Iranian EFL Learners' Speaking Proficiency. Tehran: Islamic Azad University.

Uso, E., \& Flor, A. (2006). Towards Acquiring Communicative Competence through Writing.GmbH \& Co. KG, D10785 .

Zenjanab, S. (2010). The Impact of Planned/Incidental Focus on Form on the Grammatical Accuracy of Iranian EFL Learners' Oral Production at the Intermediate Level of Language. Tehran: Islamic Azad University. 